\title{
PEMBERDAYAAN USAHA KECIL DAN MENENGAH (UKM) INDONESIA DI ERA REFORMASI
}

\author{
Salim Al Idrus"
}

\begin{abstract}
Abstrak:
Sejak pertengahan tahun 1977 situasi perekonomian Indonesia mengalami goncangan keras karena dilanda krisis ke yang berkepanjangan. Konglomerat yang diharapkan sebagai mesin pembangunan dan pertambahan ekonomi Indonesia telah mengalami kegagalan. Kedudukan dan peran UKM selama krisis telah memberikan harapan baru akan hari depan pemilihan ekonomi Indonesia. Kenyataan menumjukkan selama krisis dibanding usaha besar (konglomerat).
\end{abstract}

Kata-kata kunci: UKM, Indonesia, Reformasi.

Menurut Sutrisno (2003) kedudukan UKM dalam perekonomian Indonesia paling tidak dapat dilihat dari: (1) kedudukannya sebagai pelaku utama dalam kegiatan ekonomi di berbagai sektor; (2) penyedia lapangan kerja yang besar;

(3) pemain penting dalam pengembangan kegiatan ekonomi lokal dan pemberdayaan masyarakat. Melihat begitu pentingnya sektor UKM tidak dapat dipungkiri pada saatnya nanti sektor ini dapat menjadi penyangga ekonomi nasional.

Pada paro pertama dekade 1970-an, persoalan kesenjangan tingkat kesejahteraan pada umumnya dan kesenjangan usaha besar kecil telah menjadi perdebatan sengit dan berkepanjangan. Ketika itu pemerintah yakin betul bahwa pemerataan lambat laun akan terwujud dengan sendirinya kalau kue ekonomi nasional semakin membesar. Dalam perkembangan selanjutnya keyakinan itu hanya tinggal harapan bagai sebuah fatamorgana. UKM semakin jauh tertinggal dengan usaha besar milik para konglomerat, mereka menguasai seluruh sektor kegiatan ekonomi dari hulu sampai hilir.

Pertambahan ekonomi saat itu mengalami perkembangan yang sangat spektakuler dan mendapat julukan sebagai macan Asia. Kalau dilihat secara mendalam pertumbuhan yang tinggi itu hanyalah pertumbuhan yang semu dan sangat tidak profesional. Para pengusaha besar dapat berkembang hanya karena dekat

* Penulis adalah dosen Fakultas Ekonomi UIN Malang, sedang menyelesaikan studinya pada Pascasarjana UNM 
pénguasa waktu itu. Semua itu mencapai klimaknya setelah badai krisis melanda Indonesia, dimana para konglomerat berguguran bersamaan dengan lengsernya pemerintah Soeharto.

Prinsip yang mendasari agenda pemberdayaan UKM atau ekonomi rakyat adalah derita dan nestapa yang dialami UKM di masa lalu (Faisal, 2002). Di masa reformasi ini sektor UKM diharapkan dapat mengganti peran usaha besar dalam pembangunan ekonomi bangsa.

\section{PERAN USAHA KECIL DAN MENENGAH (UKM)}

\section{Pengakuan Peran Usaha Kecil Menengah (UKM)}

Agar permasalahan yang menyangkut sektor UKM bisa ditempatkan di dalam kerangka utuh bagi terwujudnya suatu pembaruan ekonomi yang mendasar maka diperlukan suatu landasan pijak yang kokoh dan kerangka pemikiran yang komprehensif yang memayunginya. Selama pemerintah Orde Baru pengakuan peran sektor UKM hanya berhenti pada tataran konseptual, sedang dalam realisasinya sektor UKM termarginalkan (terpinggirkan).

Upaya pemberdayaan ekonomi rakyat pada prinsipnya merupakan manifestasi dari tuntutan pembangunan ekonomi yàng berlandaskan kepada nilainilai demokrasi yang universal, yaitu menjadikan manusia sebagai objek pembangunan dengan otonomi sebagai titik tolaknya (Faisal, 2002). Berbagai potensi yang dimiliki sektor UKM harus dioptimalkan, pembangunan bukan menjadikan kota sebagai pusat pertumbuhan dengan sosok modernisasi yang menyilaukan.

Mengacu pada konsep pengakuan peran Sektor UKM, maka pemberdayaan ekonomi rakyat harus terwujud dalam dua sisi, yaitu: Pertama, perluasan basis aktor-aktor ekonomi dalam proses produksi. Kedıra, penegakan kedaulatan konsumen. Dengan demikian baik dari sisi produsen maupun konsumen harus sama-sama diberdayakan.

Kenyataan menunjukkan sektor UKM sangat beraneka ragam, baik dari segi kegiatan maupun lingkungan usaha yang dihadapinya. Oleh karena itu, karakteristik dan permasalahan yang dihadapi UKM berbeda-beda dari satu jenis kegiatan ke jenis kegiatan lainnya, dan satu lokasi ke lokasi lainnya. Realita inilah yang menyebabkan tidak dimungkinkannya dibuat suatu kebijakan nasional bagi pemberdayaan UKM yang dirancang secara sentralistis dan terinci sampai ke tingkat operașional.

Di tingkat nasional, dibutuhkan dalamsebuah komitmen politik dan dukungan bidang-bidang, baik langsung maupun tidak langsung, memperkokoh landasan bagi tumbuh dan berkembangnya UKM. Menurut Fasila, (2002) komitmen politik dari eksekutif dan parlemen paling tidak mencakup tiga hal. Pertama, keberpihakan 
yang dilandasi prinsip-prinsip pemberdayaan usaha kecil yang sangat sehat lewat penguatan daya saing dan pengembangan UKM.

Kedua, alokasi dana APBN/APBD yang cukup memadai untuk UKM sebagai conțoh cerminan dari politik anggaran. Ketiga, pembuatan peraturan perundang-undangan yang memberikan ruang gerak seluas-luasnya di satu pihak dan menghilangkan hambatan-hambatan yang dihadapi UKM.

\section{Perkembangan Usaha Kecil Menengah (UKM)}

Selama ini perkembangan UKM di Indonesia mendapat perhatian serius baik dari pemerintah maupun kalangan masyarakat luas, karena kelompok unit usaha tersebut menyumbang sangat besar kesempatan kerja. Di masa krisis ekonomi berlangsung sektor UKM lebih mampu bertahan dibanding dengan usaha skala besar.

Selama periode 1997-2001 jumlah usaha dari semua skala mengalami peningkatan secara parsial. Gambaran lebih konkret tentang perkembangan jumlah usaha skala kecil, menengah dan besar terlihat dalam Tabel 1 .

Tabel 1 Jumlah Usaha Kecil, Menengah dan Besar Tahun 1997-2001 (Unit)

\begin{tabular}{crrrrr}
\hline Variabel & \multicolumn{1}{c}{$\mathbf{1 9 9 7}$} & \multicolumn{1}{c}{1998} & \multicolumn{1}{c}{$\mathbf{1 9 9 9}$} & \multicolumn{1}{c}{$\mathbf{2 0 0 0}$} & \multicolumn{1}{c}{$\mathbf{2 0 0 1}$} \\
\hline UK & 39.704 .661 & 36.761 .689 & 37.859 .509 & 39.121 .350 & 40.137 .773 \\
\hline UM & 60.449 & 51.889 & 52.214 & 55.437 & 57.743 \\
\hline UB & 2.097 & 1.831 & 1.885 & 2.005 & 2.095 \\
\hline Tolal & 39.767 .207 & 36.815 .409 & 37.913 .608 & 39.178 .792 & 40.197 .611
\end{tabular}

Sumber: Tulus, T, 2003.

Berdasarkan data dalam Tabel 1 ternyata jumlah Usaha Kecil (UK) menunjukkan jumlah yang sangat besar, sehingga dapat dikatakan usaha ini merupakan kunci pengaman masalah ketenagakerjaan di Indonesia.

Jumlah unit UKM bervariasi menurut sektor ekonomi, dan terutama usaha kecil terkonsentrasi di pertanian, peternakan, kehutanan dan perikanan. Secara lebih konkret jumlah unit dan tenaga kerja di Industri Kecil (IK) dan Industri Kecil Rumah Tangga (IKRT) periode 1999 sampai 2001 terlihat dalam Tabel 2.

Tabel 2 Jumlah Unit dan Tenaga Kerja di Industri Kecil (IK) dan Industri Kecil Rumah Tangga (IKRT) Tahun 1999-2001 


\begin{tabular}{|l|c|c|c|}
\hline \multicolumn{1}{|c|}{ Kode Industri } & Periode & Jumlah Unit & Jumlah Pekerja \\
\cline { 3 - 4 } Industri makanan - & 1999 & 52.524 & 402.558 \\
minuman (31) & 2000 & 67.253 & 521.586 \\
& 2001 & 63.613 & 480.643 \\
Industri Tekstil & 1999 & 30.071 & 261.643 \\
Pakaian Jadi dan & 2000 & 39.122 & 332.059 \\
Kulit (32) & 2001 & 49.238 & 386.719 \\
Industri Kayu dan & 1999 & 50.472 & 13.437 \\
Perabol Keluarga & 2000 & 50.258 & 20.482 \\
& 2001 & 56.658 & 25.118 \\
Industri Kimia & 1999 & 2.535 & 22.009 \\
Minyak Bumi, & 2000 & 1.557 & 23.222 \\
Karet \& Plastik & 2001 & 3.038 & 39.741 \\
Industri Logam & 1999 & 96 & 942 \\
Mulia & 2000 & 772 & 5.896 \\
& 2001 & 397 & 4.611 \\
\hline
\end{tabular}

Sumber: Tulus, T, 2003.

Berdasarkan data Tabel 2. jumlah dan jenis unit usaha sangat bervariasi, demikian juga jumlah tenaga kerja yang dapat diserap. Data tersebut juga menunjukkan perkembangan yang cukup signifikan, dengan demikian sektor UKM mempunyai posisi yang sangat strategis bagi pembangunan ekonomi bangsa di era reformasi.

Peran sektor UKM di Indonesia dalam bentuk kontribusi out put terhadap pembentukan atau pertumbuhan Produk Domestik Bruto (PDB) cukup besar, walaupun tidak sebesar kontribusi terhadap penciptaan kesempatan kerja (Tulus, $T$, 2003). Kegiatan yang dilaksanakan oleh sektor UKM biasanya bersifat padat karya (banyak menyerap tenaga kerja).

\section{PEMBERDAYAAN USAHA KECIL MENENGAH}

Upaya pemberdayaan sektor.UKM dimaksudkan untuk meningkatkan harkat dan martabat UKM, sehingga UKM lebih mampu berperan dalam percaturan ekonomi nasional. Seringkali upaya pemberdayaan terperangkap dalam bias-bias pemberdayaan. Hal ini perlu dilakukan agar para pakar dan praktisi yang belum memahami dan mungkin tidak meyakini menjadi sadar terhadap hakikat 
pemberdayaan.

Menurut Kartasasmita (1996), pemberdayaan UKM merupakan alternatif pemecahan terhadap berbagai dilema yang dihadapi sektor UKM. Adapun berbagai bias pemberdayaan yang mungkin terjadi adalah: Bias Perfama, bahwa pemberdayaan UKKM lebih mementingkan bantuan material (modal) daripada keterampilan teknis dan manajerial. Pola anggapan semacam ini sering mengakibatkan upaya pemberdayaan itu sebagai pemborosan sumberdaya dan dana, karena kurang memperhatikan aspek keterampilan teknis dan manajerial.

Bias Kedua, anggapan bahwa pemberdayaan UKM merupakan program yang berasal dari atas (pemerintah), dan mereka yang diberdayakan kurang menjadi titik sentral pelaksanaan. Kerjasama yang baik antara pemerintah dan sektor UKM dalam proses pemberdayaan sảngat diperlukan, dengan demikian program pemberdayaan tidak bertepuk sebelah tangan. Dalam kaitan dengan bias kedua ini seringkali proyek pemberdayaan UKM habis, maka habislah program pemberdayaan.

Bias keriga, sektor UKM dianggap tidak tahu apa yang diperlukan atau bagaimana memperbaiki nasibnya. Oleh karena itu, mereka harus dituntun dan dibimbing dan tidak perlu dilibatkan dalam perencanaan meskipun yang menyangkut dirinya sendiri. Akibat dari anggapan semacam itu menjadikan proyek-proyek pemberdayaan UKM menjadi salah alamat. Dan mereka yang diberdayakan tetap menjadi tidak berdaya.

Dalam jangka panjang pemberdayaan sektor UKM harus dapat mentransformasi model pengusaha piramid menjadi model pengusaha belah ketupat. Secara lebih konkret transformasi model piramida ke belah ketupat terlihat dalam Gambar 1.

Gambar 1 Transformasi Model Piramida ke Belah Ketupat
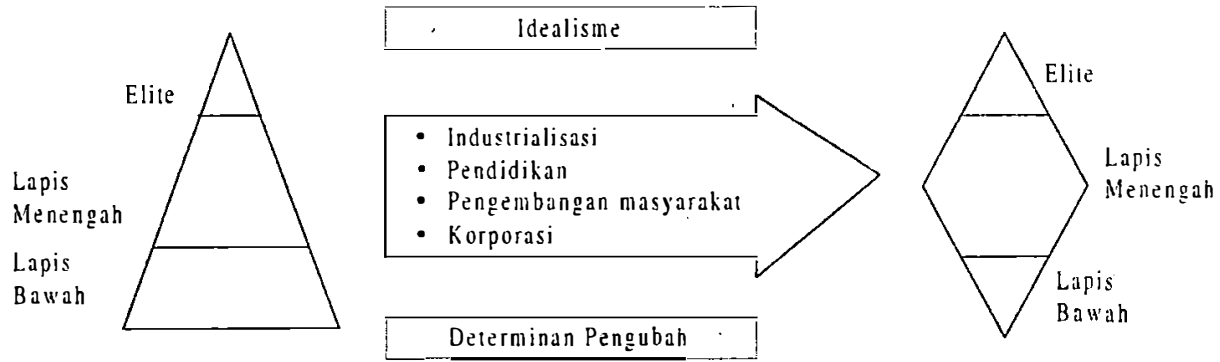

(Sumber: Muhammad, 1992)

Berdasarkan Gambar 1 profil pengusaha kita mayoritas adalah usaha kecil (lapisan bawah), yang jumlahnya sangat besar. Sedangkan sebagian kecil adalah pengusaha besar yang menguasai sebagian modal usaha. Kondisi di atas sangat 
tidak sehat ditinjau dari berbagai aspek dan bila diteruskan akan sangat menganggu pembangunan ekonomi bangsa di masa yang akan datang.

Di masa yang akan datang profil pengusaha Indonesia harus diubah menjadi belah ketupat, dimana mayoritas pengusaha adalah lapisan menengah. Kondisi semacam ini akan dapat mengurangi terjadinya kesenjangan antara kaya dan miskin.

Adapun determinan pengubah menyangkut persoalan penyempurnaan dalam sistem (pola) industrialisasi, pendidikan, pengembangan masyarakat dan juga pengembangan korporasi. Semuanya itu akan dapat dijalankan apabila dilandasi oleh semangat idealisme yang mencerminkan kebersamaan kita sebagai bangsa. Pembangunan ekonomi itu pada hakikatnya untuk kemakmuran seluruh bangsa, yaitu bangsa Indonesia.

Apabila profil model pengusaha belah ketupat dapat dicapai, itu maknanya sektor UKM akan benar-benar menjadi tulang punggung perekonomian nasional. Amanat konstitusi (UUD 1945) akan terealisasi dalam kenyataan dan. semuanya itu akan dapat mendukung proses keutuhan negara dan sekaligus menjamin terjadinya stabilitas ekonomi nasional.

Semangat idealisme harus menjadi dasar setiap kebijakan yang dapat mempengaruhi bekerjanya determinan pengubah. Idealisme yang dipandang sebagai sebuah komitmen yang wajib dilaksanakan dan bukan sebuah retorika. Komitmen ini penting khususnya bagi pemimpin atau para pengambil keputusan, karena dengan kekuasaan dan wewenang yang dimiliki dapat mempengaruhi determinan pengubah.

Industrialisasi yang dilakukan harus mencerminkan sumberdaya manusia yang kreatif dan inovatif, sehingga produk yang dihasilkan mempunyai daya saing yang tinggi, baik dalam pasar domestik maupun dalam pasar global. Pendidikan dalam arti luas menjadi jalur yang penting dalam mengupayakan transformasi itu.

Pengembangan masyarakat di sini mengandung makna sikap masyarakat kewirausahaan. Jiwa dan semangat wirausaha harus ditanamkan dalam masyarakat. Ini semua dimaksudkan untuk membangun masyarakat sektor UKM.

\section{KESIMPULAN}

Pembangunan sektor ekonomi rakyat harus menjadi sebuah komitmen nasional demi masa depan bangsa. Peran sektor UKM di era reformasi cukup mempunyai posisi yang strategis untuk mengganti peran yang dimainkan oleh konglomerat di masa lalu.

Program pemberdayaan sektor UKM harus menjadi prioritas utama pembangunan ekonomi rakyat. Program pemberdayaan ini harus realistis dan berkesinambungan serta jauh dari sekadar retorika. Pada akhir nanti profil model 
pengusaha belah ketupat akan menjadi kenyataan. Apabila semua itu dapat terjadi, kemakmuran seluruh rakyat akan nienjadi tujuan nyata dari kehidupan berbangsa dan bernegara.

\section{DAFTAR RUJUKȦN}

Faisal, B. 2002. Perekonomian Indonesia: Tantangan dan Harapan Bagi Kebangkitan Iridonesia. Jakarta: Erlangga.

Krisnamurthi, B. 2003. Usaha Mikro, Kecil dan Menengah: Ekonomi Rakyat dengan Cara Berekonomi Mereka Sendiri. Makalah disajikan dalam Konggres ISE Ke XV, Malang 13-5 Juli.

Kartasasmita, G. 1996. Pembangunan Untuk Rakyat: Memadukan Pertumbuhan dan Pemerataan. Jakarta: Pustaka Cisindo.

Muhammad, F. 1992. Peranan Sumberdaya Manusia Dunia Usaha. Yogyakarta: UGM Press.

Sutrisno, N. 2003. Kewirausahaan dalam Pengembaingan UKM di Indonesia. Makalah Disajikain dalam Konggres ESEİ KE XV, Malang, 13-15 Juli.

Tulus, T. 2003. Prospek UKM Indonesia di dalam Eral Perdagangan Bebas dan Globalisasi Ekonomi Dunia. Makalah Disajikan dalam Konggres ISEI Ke XV, Malang 13-15 Juli. 